AnNA StrojnA-KRZYSTANEK

ORCID 0000-0003-1690-1543

Biblioteka Politechniki Krakowskiej

\title{
KOBIETY \\ NA POLITECHNICE LWOWSKIEJ
}

\begin{abstract}
Strojna-Krzystanek Anna, Kobiety na Politechnice Lwowskiej [Women at the Lviv Polytechnic]. Studia Edukacyjne nr 53, 2019, Poznań 2019, pp. 423-436. Adam Mickiewicz University Press. ISSN 1233-6688. DOI: $10.14746 /$ se.2019.53.24

The author of the article wants to picture the education opportunities for females in the 19th and 20th centuries at higher education institutions. The article brings forward the characters of women associated before World War II with the oldest technical university in Poland, the Lviv Polytechnic, detailing their contribution to the development of Polish science.
\end{abstract}

Key words: education of women in the XIX centurie, education of women in the XX centurie Lviv Polytechnic, interwar period

Wydawać by się mogło, że pisząc o historii kobiet w szkołach wyższych na ziemiach polskich, sięgniemy do bardzo odległych czasów. Tymczasem, za początek możemy umownie przyjąć dopiero rok 1897, kiedy to kobiety zostały oficjalnie włączone do edukacji akademickiej. Badacze historii oświaty chętnie podejmowali temat wykształcenia kobiet $\mathrm{w}$ XIX wieku i na początku XX wieku, skupiając się głównie na ich obecności oraz roli w środowiskach uniwersyteckich. Trudno jednak natrafić na opracowania podejmujące ten temat $\mathrm{w}$ odniesieniu do uczelni technicznych.

Kobiety nie mogły studiować, a przyczyn takiego stanu rzeczy należy szukać w nałożonych na nie ograniczeniach społecznych i formalnych. Charakter tych pierwszych można oddać, powtarzając za Marią Magdaleną Beszterdą:

Wciąż w najlepsze się miała tendencja do wychowywania panienek na mimozy i łaskawe flamy, które strzelały oczyma zza wachlarza w poszukiwaniu męża albo zdo- 
bywały tak niezbędne do życia umiejętności jak haftowanie na kordonku czy gamy na pianinie ${ }^{1}$.

Powodów formalnych należy zaś upatrywać w systemach oświaty panujących na terenie zaborów. Na szczególną uwagę zasługuje zabór austriacki, w obrębie którego znalazła się lwowska politechnika. Od momentu założenia uczelni technicznej we Lwowie przepisy jasno określały, że przepustkę do studiowania, jak i dyplom szkoły wyższej mogą otrzymać absolwenci, którzy wykażą się „świadectwem ukończenia z dobrym postępem szkoły realnej lub gimnazjum"2. Maturę można było uzyskać, zdając kończący szkołę średnią egzamin państwowy. Nie byłoby w tym nic szczególnego, gdyby nie fakt, że kształcenie państwowe dla obu płci ograniczało się do etapu szkoły powszechnej. Szkoły średnie państwowe były przeznaczone tylko dla mężczyzn. Nieliczne prywatne gimnazja żeńskie miały odrębny program nauczania, ponadto obowiązujące przepisy zabraniały tym instytucjom przeprowadzania egzaminu dojrzałości. Tak więc formalne wymogi, poparte panującym powszechnie przekonaniem o niemożności uczestnictwa kobiet $\mathrm{w}$ nauce ze względu na posiadane przez nie cechy biologiczne i psychiczne ${ }^{3}$, decydowały o tym, że płeć była wyznacznikiem poziomu wykształcenia Polaków.

Zmiany w sposobie kształcenia kobiet na ziemiach polskich w II połowie XIX wieku wymusiła jednak sytuacja społeczno-polityczna. Zrywy niepodległościowe, ukaz uwłaszczeniowy chłopów spowodowały między innymi na tyle głębokie przeobrażenia w strukturze społecznej, że również głos kobiet w sprawie równouprawnienia naukowego i zawodowego stał się donośniejszy. Prace rozpoczęto od niezbędnego reformowania szkolnictwa średniego. W ich przebieg włączyły się organizacje społeczne, kościelne oraz prywatne osoby, które podjęły się zakładania gimnazjów żeńskich z nowatorskim, jak na owe czasy, programem nauczania. Szkoły te wyrównując poziom kształcenia w stosunku do gimnazjów męskich, z czasem w niczym im już nie ustępowały.

Kobiety pozbawione jednak możliwości kontynuowania nauki na rodzimych uczelniach, zostały niejako zmuszone do studiowania poza granicami kraju. W roku 1863 jako pierwszy swoje podwoje dla polskich studentek otworzył uniwersytet w Zurychu. Polki studiowały jeszcze we Francji, Anglii, Belgii ${ }^{4}$. O ich wielkiej determinacji w zdobywaniu wiedzy może

${ }^{1}$ M.M. Beszterda, Stryjeńska. Diabli nadali: Lambda alboskrzydła pod tózkiem: recenzje, http:/ / ksiazki.onet.pl/recenzje/stryjenska-diabli-nadali-angelika-kuzniak-recenzja/scf3ff [dostęp: 19.07.2017].

${ }^{2}$ W. Zajączkowski, C. k. Szkoła politechniczna we Lwowie, Lwów 1889, s. 35.

3 A. Kołodziejczyk, Czy kobiety sa dyskryminowane w nauce? A w innych dziedzinach?, http:/ / pg.edu.pl/documents/1152961/1184550/calosc.pdf, [dostęp: 19.07.2017].

4 A. Dominiczak, Edukacja kobiet, http://www.cpk.org.pl/plik,66,edukacja-kobiet-pdf. pdf, [dostęp: 19.07.2017]. 
poświadczyć fakt, iż to one (obok Rosjanek) stanowiły największą grupę obcych studentek uczelni w Paryżu i Monachium. Studiowały na uniwersytetach, głównie medycynę ${ }^{5}$. Kiedy niektóre Polki wyjeżdżały na studia za granicę, w Polsce we wszystkich zaborach zaczęto otwierać instytucje, które stanowiły substytut szkół wyższych. Pierwszą tego rodzaju instytucję założył w 1868 roku Adrian Baraniecki w Krakowie. Podstawowym założeniem Wyższych Kursów dla Kobiet była ich dostępność. Mogły w nich uczestniczyć wszystkie kobiety, bez względu na pochodzenie klasowe czy wyznanie. Wysoki poziom nauczania sprawił, że z czasem zaczęli na nie uczęszczać również mężczyźni.

Ten sposób zdobywania wiedzy zyskał ogromną popularność od samego początku. Podjęto nawet starania o przekształcenie tej instytucji w szkołę wyższą dla kobiet, ale inicjatywa spotkała się ze stanowczym sprzeciwem władz austriackich. Widząc jednak rosnące zainteresowanie kursami, dokonano zmian organizacyjnych i roczny kurs przekształcono $w$ dwuletni. Naukę można było pobierać na wydziałach: Historyczno-Literackim, Przyrodniczym oraz Sztuk Pięknych. Wykładowcami byli profesorowie Uniwersytetu Jagiellońskiego, Akademii Sztuk Pięknych, a także literaci. W trakcie funkcjonowania Wyższych Kursów dla Kobiet, czyli do 1924 roku, ukończyło je prawie 7 tysięcy kobiet. Wśród absolwentek było wiele znanych osobowości, jak Olga Boznańska, czy związana później z Politechniką Lwowską Helena Krzemieniewska.Wśród liczących się inicjatyw tego typu należy wymienić jeszcze Uniwersytet Latający. Działał on w Warszawie od 1883 do 1905 roku, a w 1906 został przekształcony w Towarzystwo Kursów Naukowych. Uniwersytet zwany był też "babskim”, bo około 70 procent słuchaczy stanowiły kobiety. W 1893 roku prowadzono tam wykłady na trzech wydziałach: Nauk Społecznych, Historyczno-Filologicznym (z Pedagogiką) oraz Matematyczno-Przyrodniczym ${ }^{6}$. Wysoko wykwalifikowana kadra nauczycielska i poziom nauczania, wyższy niż na zrusyfikowanym Uniwersytecie Warszawskim, sprawiły, że ukończyło go prawie 5 tysięcy kobiet ${ }^{7}$. Do najsławniejszych absolwentek należały: Maria Skłodowska-Curie, Alicja Dorabialska, Jadwiga Sikorska i Stanisława Dowgiałłówna - późniejsze pierwsze wolne słuchaczki tak zwanej hospitantki Uniwersytetu Jagiellońskiego.

Wymienione instytucje dostarczały wiedzy na poziomie szkół wyższych, jednak ich absolwenci nie mieli uprawnień do wykonywania wyuczonego zawodu. Absolwentki kursów bardzo często kontynuowały więc naukę na

${ }^{5}$ J. Suchmiel, Emancypacja naukowa kobiet w uniwersytetach w Krakowie i Lwowie do roku 1939, http://dlibra.bg.ajd.czest.pl:8080/Content/2868/Pedagogika_13_115.pdf, [dostęp: 20.09.2017].

${ }^{6}$ D. Zamojska, Akademicy i urzędnicy: kształtowanie ustroju państwowych szkót wyższych w Polsce 1915-1920, Warszawa 2009, s. 23.

7 P. Bunio i in., Idealistki, siłaczki, reformatorki: kobiety w nauce polskiej, Łódź 2007, s. 16. 
studiach zagranicznych, ponieważ dopiero uzyskanie dyplomu ukończenia studiów pozwalało podjąć pracę zawodową.

Studiując za granicą, kobiety zetknęły się z ruchem feministycznym, coraz szerzej rozlewającym się na Europę. Polki również włączyły się w walkę o równouprawnienie, przy czym w Polsce feminizm miał inny wydźwięk. Z największą siłą wyrażał się właśnie w kwestii walki o oświatę. „Największą krzywdą jest więc brak oświaty" - pod tym hasłem polskie feministki zaczęły domagać się prawa do studiowania, prawa do nauki. Władze uczelni nie zajęły oficjalnego stanowiska względem tych żądań i nowej sytuacji. Wielokrotnie do zwierzchników w Wiedniu kierowano więc zapytania o wykładnię, jak postępować kiedy o przyjęcie na studia ubiegają się panie. Wreszcie w 1878 roku Ministerstwo Wyznań i Oświecenia wydało rozporządzenie o uczęszczaniu kobiet na wykłady w charakterze hospitantek. Tym samym, aktem tym uregulowano sprawę kobiet studiujących na zagranicznych uczelniach, zezwalając na nostryfikację uzyskanych przez nie dyplomów.

Ten pozornie rewolucyjny dokument nie rozwiązywał w pełni występujących problemów. Mając na względzie jakość kształcenia, stwierdzono, że na najwyższym etapie musi się ono odbywać dla każdej płci oddzielnie. Mogło wydawać się, że ten idący naprzeciw oczekiwaniom płci pięknej zapis ułatwi wstęp na uczelnie. W praktyce wyglądało inaczej.

Brak możliwości finansowych, organizacyjnych i sprzeciw konserwatywnego środowiska akademickiego spowodowały, że nie wprowadzono takiego rozwiązania, które by to umożliwiło. W wyjątkowych przypadkach kobiety mogły być "dopuszczone do regularnych dla męskiej młodzieży przeznaczonych wykładów uniwersyteckich". Warunkiem miało być uzyskanie pozwolenia od prowadzącego wykład i rady wydziału na uczelni. Jeśli kobieta zdobyła takie pozwolenie, to i tak przepis zabraniał jej uzyskania statusu studenta nadzwyczajnego, zaliczeń i urzędowych poświadczeń o uczęszczaniu na studia, także dopuszczenia do wykładów. Kobiety mogły być wyłącznie hospitantkami, czyli mogły przybywać na uczelnie „zawsze tylko na pojedyncze, wyraźnie oznaczone wykłady" ${ }^{8}$.

Mimo tych ograniczeń, w 1880 roku wpłynął pierwszy wniosek o zgodę na studiowanie na Uniwersytecie Jagiellońskim, a w latach następnych napływały kolejne. Jednak do 1894 roku żadnej kobiecie, powołującej się na to rozporządzenie, nie pozwolono uczestniczyć w wykładach. Przełom nastąpił niespodziewanie w 1894 roku, podczas Kongresu Pedagogicznego we Lwowie, kiedy to Kazimiera Bujwidowa w zaimprowizowanym przemówieniu przekonała większość uczestników spotkania do głosowania za

${ }^{8}$ W.K. Kumaniecki, Zbiór najważniejszych przepisów uniwersyteckich, [s.n.], Kraków 1913, s. $45-46$. 
możliwością studiowania kobiet na polskich uniwersytetach w charakterze zwyczajnych słuchaczek. Środowisko akademickie nie mogło dłużej wykazywać biernej postawy wobec zmian, jakie dokonywały się w procesie edukacji kobiet. Wpłynięcie kolejnych podań o zgodę na studia na Uniwersytecie Jagiellońskim spowodowało oficjalną debatę o edukacji kobiet na szczeblu wyższym. W tym samym roku przyjęte zostały na studia trzy farmaceutki: Janina Kosmowska, Jadwiga Sikorska i Stanisława Dowgiałłówna ${ }^{9}$. Słusznie upominały się one o pełne prawa jako studentki. Samo zdobycie wykształcenia już nie wystarczało, one chciały pracować w wyuczonym zawodzie. Jednakże, przepisy na uniwersytetach jasno stwierdzały, że tylko matura daje prawo do studiowania i zdobycia dyplomu. Pokonanie tej formalnej przeszkody nastąpiło dopiero w 1896 roku. Wtedy utworzono pierwsze gimnazjum żeńskie z programem odpowiadającym gimnazjum męskiemu, a dziewczęta zostały dopuszczone do egzaminów maturalnych na zasadach obowiązujących w szkołach męskich ${ }^{10}$. W niedługim czasie władze Uniwersytetu Jagiellońskiego podjęły decyzję i w 1897 roku oficjalnie zezwoliły kobietom na studiowanie na Wydziale Filozoficznym, a w 1900 roku - na Wydziale Lekarskim ${ }^{11}$.

Środowisko profesorów szkół wyższych w kwestii kształcenia kobiet na szczeblu wyższym było podzielone. Wielu przejawiało podejście konserwatywne, całkowicie wykluczając udział kobiet w tej formie edukacji. Nie brakowało też profesorów aprobujących i wspierających dążenia płci pięknej. Ich postawa była niejako kompromisem wypracowanym pomiędzy obowiązującymi jeszcze przepisami, które zakazywały kobietom nauki w szkołach wyższych, a presją wywieraną przez coraz liczniejszą grupę pań zabiegających o możliwość studiowania. Wielu włączyło się więc w działania, realnie pomagając im w dostępie do wiedzy. Jako przykład można wymienić prowadzone przez profesorów Uniwersytetu Jagiellońskiego wykłady na Wyższych Kursach dla Kobiet w Krakowie ${ }^{12}$.

Lwowskie środowisko jeszcze inaczej ustosunkowało się do problemu kształcenia kobiet na Uniwersytecie Jana Kazimierza. W 1896 roku władze tej uczelni podjęły decyzję o uruchomieniu Towarzystwa Kursów Akademickich dla Kobiet. Oferta była skierowana tylko i wyłącznie do kobiet. Ta

\footnotetext{
${ }^{9}$ A. Smywińska, W poszukiwaniu prababek - o pierwszych filozofkach z Uniwersytetu Jagiellońskiego (1897-1939) http://etyka.uw.edu.pl/wp-content/uploads/2013/6/45scrd/09-Smywinska-w-poszukiwaniu-prababek.pdf, [dostęp: 20.07.2017].

${ }^{10}$ Szkolnictwo i oświata w Galicji 1772-1918, red. nauk. Julian Dybiec i in., Rzeszów 2015, s. 85 .

${ }^{11}$ U. Perkowska, Kobiety $w$ Uniwersytecie Jagiellońskim, https://forumakademickie.pl/ fa-archiwum/archiwum/99/7-8/artykuly/kobiety_na_uj.htm , [dostęp: 20.07.2017].

${ }_{12}$ R. Terlecki, Oświata dorostych i popularyzacja nauki w Galicji w okresie autonomii, Wrocław 1990, s. 121.
} 
słuszna inicjatywa okazała się, niestety, spóźniona ${ }^{13}$. Otwarcie UJ dla kobiet w 1897 roku spowodowało, że pomimo początkowo dużej frekwencji kursy zamknięto już w 1899 roku.

Udział kobiet $\mathrm{w}$ życiu, kształceniu na uczelniach systematycznie wzrastał. Naturalna stała się więc ich potrzeba oraz chęć pracy naukowej w tych placówkach. W 1907 roku uzyskały one zgodę na zajmowanie stanowisk asystenckich na uniwersytetach ${ }^{14}$. Był to kolejny krok ku większej swobodzie i zaznaczaniu obecności kobiet $\mathrm{w}$ nauce. $\mathrm{W}$ zupełnie odmiennej sytuacji były kobiety, które chciały studiować nauki ścisłe na Politechnice Lwowskiej. Ta uczelnia nadal pozostawała dla nich niedostępna. Przełom nastąpił w 1911 roku.

Rok, w którym Polska odzyskała niepodległość, przyniósł kobietom formalną równość polityczną i społeczną. Obecność kobiet na politechnice została usankcjonowana rozporządzeniem wydanym w 1919 roku.

Od roku naukowego 1919/20 począwszy, kobiety ubiegające się o przyjęcie na słuchaczki zwyczajne mogą być zapisywane w tym charakterze, o ile wykażą się warunkami wymaganemi przy zapisie od kandydatów na słuchaczów zwyczajnych ${ }^{15}$.

Od 1918 roku władze oświatowe rozpoczęły intensywną pracę nad scalaniem wielu modeli kształcenia w jeden system edukacji. Do prac nad nową ustawą dotyczącą szkolnictwa zostali zaproszeni przedstawiciele środowiska krakowskiego i lwowskiego. Zaskakująca była postawa tego ostatniego, reprezentowanego przez Uniwersytet Jana Kazimierza i Politechnikę Lwowską, względem profesury kobiet. W projekcie do ustawy rzecznicy tych instytucji uznali, że „Profesorami mogą być tylko mężczyźni"16. Na szczęście ten zapis nie zyskał aprobaty i został skreślony. Nowa ustawa zaczęła obowiązywać od 1920 roku. Kobiety mogły studiować i zdobywać stopnie doktorskie. Coraz liczniej obsadzano nimi niższe stanowiska naukowe. Ruszyły więc szturmem na Politechnikę ${ }^{17}$.

W historię każdego wydziału Politechniki Lwowskiej wpisane są losy wielu kobiet, których biografie stanowią nie tylko ilustrację przemian zachodzących w oświacie, ale również świadectwo ich indywidualnego wkładu w rozwój nauki.

13 Szkolnictwo i oświata w Galicji 1772-1918, s. 275.

14 Kobieta i kultura: kobiety wśród twórców kultury intelektualnej i artystycznej w dobie rozbiorów i w niepodległym pańskie polskim, red. A. Żarnowska, A. Szwarc, Warszawa, 1996, s. 141.

${ }_{15}$ Program Szkoty Politechnicznej we Lwowie na rok naukowy 1920/21, http:/ / delibra.bg.polsl. pl/dlibra/docmetadata?id=117, [dostęp: 20.07.2017].

16 D. Zamojska, Akademicy i urzędnicy, s. 166.

17 J. Piłatowicz, Politechnika Lwowska w dwudziestoleciu międzywojennym, http://bazhum. muzhp.pl/media//files/Kwartalnik_Historii_Nauki_i_Techniki/Kwartalnik_Historii_ Nauki_i_Techniki-r1991-t36-n1/Kwartalnik_Historii_Nauki_i_Techniki-r1991-t36-n1-s25-70/ Kwartalnik_Historii_Nauki_i_Techniki-r1991-t36-n1-s25-70.pdf, [dostęp: 20.07.2017]. 
Największą popularnością wśród kobiet cieszył się Wydział Chemiczny Politechniki Lwowskiej. Ze statystyk wynika, że w dwudziestoleciu międzywojennym co trzecia/czwarta studentka tej uczelni wybierała właśnie chemię. Chemiczki stanowiły również najliczniejszą grupę absolwentek. Aż 68 spośród ponad 180 dyplomów uzyskanych przez kobiety na Politechnice w latach 1918-1939 należało do pań o wykształceniu inżyniera chemika ${ }^{18}$.

Jedną z pierwszych studentek Wydziału Chemicznego była Maria Huelle, córka profesora Politechniki Lwowskiej - Tadeusza Fiedlera. Studia rozpoczęła na Uniwersytecie Jana Kazimierza, ale kiedy tylko Politechnika umożliwiła kobietom naukę, od razu przeniosła się na tę uczelnię. Pracowała w latach 1920-1925 jako asystentka w Katedrze Technologii Chemicznej.

W historię Politechniki Lwowskiej jako pierwsza kobieta doktor wpisała się Bogusława Jeżowska-Trzebiatowska. Dysertację obroniła w 1935 roku, a z Wydziałem Chemicznym uczelni była związana od 1926 roku. Po studiach pracowała na wydziale jako asystentka - aż do wybuchu II wojny światowej. Po wojnie osiedliła się we Wrocławiu i brała udział w organizowaniu Wydziału Chemicznego na Uniwersytecie Wrocławskim oraz Politechnice Wrocławskiej $^{19}$.

Z Wydziałem Chemicznym Politechniki Lwowskiej związana była również Alicja Dorabialska, znana w środowisku naukowym jako pierwsza kobieta $\mathrm{z}$ tytułem profesora. Przebieg jej kariery naukowej jest odzwierciedleniem drogi, jaką w XX wieku musiały pokonać kobiety, które pragnęły się uczyć. Pomimo że ukończyła szkołę średnią i zdała maturę, naukę postanowiła kontynuować w substytucie szkoły wyższej - Towarzystwie Kursów Naukowych w Warszawie oraz na Wyższych Kursach Żeńskich w Petersburgu, zwanych Bestużewowskimi. Od chwili uzyskania niepodległości związana była przez wiele lat z warszawskim ośrodkiem naukowym. Doktoryzowała się na Uniwersytecie Warszawskim, a habilitację uzyskała na Politechnice Warszawskiej. Na stanowisku asystentki Politechniki Warszawskiej była zatrudniona do 1934 roku (w tym okresie przez 2 lata pracowała w Instytucie Radowym pod kierunkiem Marii Curie-Skłodowskiej w Paryżu).

Niespodziewanie w 1932 roku Alicja Dorabialska otrzymała nominację profesorską na Wydziale Chemicznym Politechniki Lwowskiej. Niestety, środowisko lwowskich chemików było podzielone, jednak w większości nieprzychylnie nastawione do kobiety z tytułem profesora ${ }^{20}$. Również większość profesorów innych wydziałów uznawała wprowadzenie kobiety na uczelnię

18 Tamże.

19 J. Rozynek, Doktorzy honoris causa Uniwersytetu Wrocławskiego 1948-1992, http:/ / uni.wroc. pl/o-nas/nagrody-i-wyr\%C3\%B3\%C5\%BCnienia/doktorzy-honoris-causa/bogus\% C5\%82awa-je\%C5\%BCowska-trzebiatowska [dostęp: 20.07.2017].

${ }^{20}$ Uzyskała poparcie tylko od prof. Wiktora Jakóba i Adolfa Joszta. 
za niedopuszczalne obniżenie poziomu i powagi politechniki ${ }^{21}$. Sprawa została rozwiązana dopiero w 1934 roku, dzięki Józefowi Piłsudskiemu. Obecnie z uśmiechem czytamy o okolicznościach, w jakich Dorabialska została profesorem:

Na jakimś przyjęciu w Belwederze ówczesny minister WR i OP Wacław Jędrzejewski zwrócił się do marszałka:

- Panie Marszałku! Mamy kłopot. Kandydatką na Katedrę Chemii Fizycznej na Politechnice Lwowskiej jest kobieta, Alicja Dorabialska.

- No to co? - huknął Marszałek

- Niech się baba pokażèe.

Pani profesor pracowała na Wydziale Chemicznym Politechniki Lwowskiej do 1939 roku, pełniąc w roku akademickim 1936/1937 funkcję dziekana. Z czasem została zaakceptowana przez środowisko akademickie. W 1939 roku opuściła Lwów. Rozstała się z uczelnią, ale nie z chemią. W czasie wojny wykładała ten przedmiot na tajnych kompletach Politechniki Warszawskiej. Pod koniec wojny, kiedy zaczęły się formować nowe ośrodki naukowe w Polsce, została zaangażowana w organizację nowo tworzącego się Wydziału Chemicznego Politechniki Łódzkiej.

Z osobą Alicji Dorabialskiej i z Politechniką Łódzką związana była Eligia Turska. Studiowała chemię na Wydziale Chemicznym Politechniki Warszawskiej, ale kiedy Alicja Dorabialska wyjechała na Politechnikę Lwowską, udała się do Lwowa i rozpoczęła tam pracę na stanowisku asystentki. We Lwowie zawiązała się przyjaźń, która zaowocowała wieloletnią współpracą naukową. Profesor Dorabialska była promotorem pracy doktorskiej Eligii Turskiej, a po wojnie obie brały udział w organizowaniu Katedry Chemii Fizycznej Polimerów na Politechnice Łódzkiej. W latach 70. XX wieku Eligia Turska związała się z Politechniką Śląską ${ }^{23}$.

Po II wojnie światowej chemiczki Politechniki Lwowskiej los rozrzucił po całej Polsce. Dzięki swojej pracy cieszyły się już tak dużym uznaniem na polu naukowym, że po wojnie mogły angażować się w prace nad organizowaniem większości polskich ośrodków nauki. Współorganizowały wydziały chemiczne na politechnikach: warszawskiej, łódzkiej, śląskiej, czy wrocławskiej.

Jedną z takich osób była Czesława Troszkiewiczowa. Z Politechniką Lwowską związana była od 1925 roku, kiedy to rozpoczęła studia na Wydziale Chemicznym, egzamin dyplomowy złożyła w 1934 roku, uzyskując stopień

${ }^{21}$ J. Piłatowicz, Politechnika Lwowska w dwudziestoleciu międzywojennym.

${ }^{22}$ J. Kroh, Wspomnienie o profesor Alicji Dorabialskiej, Zeszyty Historyczne Politechniki Łódzkiej, 2002, 1, s. 55.

${ }^{23}$ S. Połowiński, Prof. dr inż. Eligia Turska (1909-1996), Zeszyty Historyczne Politechniki Łódzkiej, 2007, 5, s. 103-106. 
inżyniera chemika. Jeszcze w trakcie studiów, w 1930 roku, rozpoczęła pracę zawodową $\mathrm{w}$ charakterze zastępcy asystenta, a po obronie dyplomu kontynuowała ją na etacie starszego asystenta w Katedrze Chemii Organicznej na Wydziale Chemicznym Politechniki ${ }^{24}$. Pracowała na uczelni przez cały okres wojny. Kiedy wiadomo było, że Politechnika nie będzie już uczelnią polską, wyjechała do Gliwic, gdzie uczestniczyła w organizacji nowo powstającej uczelni - Politechniki Śląskiej ${ }^{25}$.

Z ośrodkiem naukowym utworzonym po wojnie we Wrocławiu splotły swe losy dwie lwowskie chemiczki. Pierwszą była Zofia Skrowaczewska absolwentka Wydziału Chemicznego Politechniki Lwowskiej. W latach 19311945 zatrudniona jako młodszy asystent tego Wydziału, po wojnie podjęła pracę na Politechnice Wrocławskiej, uczestnicząc w pracach powołujących do życia tę uczelnię ${ }^{26}$. Drugą była Maria Witkiewiczowa, z domu Hamerska. Jako córka profesora Politechniki - profesora Wiktora Hamerskiego - odebrała gruntowne i wszechstronne wykształcenie. Studiowała na Uniwersytecie Jana Kazimierza we Lwowie i na tej uczelni zdobyła również stopień doktora. Na Politechnice Lwowskiej, na Wydziale Chemii pracowała tylko rok w roli asystentki. Względy rodzinne zdecydowały o zakończeniu pracy naukowej. W czasie wojny doświadczyła wielkiej rodzinnej tragedii. Jej mąż - profesor Roman Witkiewicz i brat - Edward Hamerski (obaj związani z Politechniką Lwowską) stali się ofiarami mordu profesorów na Wzgórzach Wuleckich w $1941 \mathrm{roku}^{27}$. Po wojnie wróciła do Polski i w 1946 roku rozpoczęła pracę na etacie asystenta w Zakładzie Mineralogii Wydziału Nauk Przyrodniczych Uniwersytetu we Wrocławiu. Wiele lat poświęciła na uporządkowanie, opisanie, sklasyfikowanie uniwersyteckich zbiorów mineralogicznych ${ }^{28}$.

Drugim wydziałem, który cieszył się dużym zainteresowaniem kobiet na Politechnice Lwowskiej był Wydział Rolniczo-Lasowy. Niewiele jest opracowań, które pozwoliłyby odtworzyć, ile kobiet po raz pierwszy wstąpiło $\mathrm{w}$ jego mury i w którym roku. Na podstawie rozproszonych informacji w literaturze przedmiotu można podać, że w 1919 roku na wydział przyjęto 20 studentek. Przez kolejne 20 lat liczebność słuchaczek wydziału utrzymy-

${ }^{24}$ Z. Popławski, Wykaz pracowników naukowych Politechniki Lwowskiej w latach 1844-1945, Kraków 1994, s. 193.

25 K. Walczak, Prof. dr inż. Czestawa Troszkiewicz (1902-1985), http:/ / www.chemia.polsl.pl/ stowarzyszenie/index.php/profesorowie/86-wydzial/profesorowie/122-prof-dr-inz-czeslawa-troszkiewicz, [dostęp: 20.07.2017].

26 J. Młochowski, Wspomnienie o profesor Zofii Skrowaczewskiej, Wiadomości Chemiczne, 1996,50 , s. 3-4.

27 K. Klimas, In memory dr Maria Witkiewiczowa, http://gs.ing.pan.pl/35_PDF/GS35_6970_Witk.pdf, [dostęp: 20.07.2017].

${ }_{28}$ Historia Muzeum Mineralogicznego Uniwersytetu Wrocławskiego i jego zbiorów, http:/ / www. muzmin.ing.uni.wroc.pl/teksty.php?plik=muzeum.php, [dostęp: 20.07.2017]. 
wała się na tym samym poziomie. Jedną z pierwszych absolwentek była Stanisława Fiedlerówna - druga córka profesora Tadeusza Fiedlera, dziekana i rektora Politechniki Lwowskiej. Przez dwa lata pracowała w Katedrze Rolnictwa.

Większość kobiet obejmowała na „Rolasie” stanowiska pomocnicze, i to na krótko. Ich wkład w naukę nie był imponujący i nie zdobyły tylu tytułów naukowych co chemiczki. Wśród niewielu kobiet, które pracowały tu naukowo należy wymienić Zofię Dubiską. Po ukończeniu studiów w 1929 roku rozpoczęła pracę na Politechnice Lwowskiej pełniąc obowiązki młodszego asystenta w Katedrze Uprawy Roli i Roślin. Pracowała zaledwie rok. Po wojnie wraz z mężem, profesorem Józefem Dubiskim, przeniosła się do Olsztyna i w tamtejszej Wyższej Szkole Rolniczej kontynuowała pracę naukową, zajmując się hodowlą zwierząt.

Kobietą, która wniosła największy wkład w rozwój nauki była Helena Krzemieniewska. Jej edukacja przypadła na czasy, kiedy uczelnie w Polsce dopiero zaczynały otwierać przed kobietami swoje drzwi, a status studentki nie było wcale tak łatwo uzyskać. W Krakowie w 1896 roku ukończyła Wydział Przyrodniczy na Wyższych Kursach Naukowych dla Kobiet im. Adriana Baranieckiego. W latach 1896-1900 studiowała, jako wolny słuchacz, na Uniwersytecie Jagiellońskim matematykę, a następnie nauki przyrodnicze, specjalizując się w fizjologii roślin. W 1919 roku przeniosła się wraz z mężem do Lwowa, gdzie objęła stanowisko zastępcy profesora botaniki na Wydziale Rolniczo-Lasowym Politechniki Lwowskiej. Pracowała na tym stanowisku do 1924 roku. Od 1925 roku skupiła się na pracy naukowej i współpracowała z mężem Sewerynem, botanikiem. Nominacją z 1 kwietnia 1946 roku została powołana na stanowisko profesora zwyczajnego na będącym w trakcie organizacji Uniwersytecie Wrocławskim, gdzie objęła Katedrę Fizjologii Roślin. Stworzyła tam własną Szkołę Fizjologów i Mikrobiologów ${ }^{29}$.

Poprzez studia na Wydziale Rolniczo-Lasowym związała swą historię z Politechniką Lwowską również Wanda Szczepuła. Niestety, wybuch wojny przerwał jej edukację. Po wojnie wspólnie z mężem ukończyła studia w Krakowie, a następnie przeniosła się na Wydział Chemiczny Politechniki Gdańskiej. Wanda Szczepuła była pierwszą kobietą, która uzyskała tytuł profesora na Politechnice Gdańskiej ${ }^{30}$.

Wśród absolwentek Wydziału Rolniczo-Lasowego należy wymienić jeszcze Janinę Syniewską - córkę chemika, profesora Politechniki Lwowskiej, Wiktora Syniewskiego. Studiowała na Uniwersytecie Jana Kazimierza

${ }^{29}$ J. Buda, Materiaty Seweryna i Heleny Krzemieniewskich (1871-1945; 1978-1966) (III-174), http://www.petea.home.pl/apan/files/user_files2/biuletyn51.pdf, [dostęp: 16.08.2017].

${ }^{30}$ K. Murawski, Gdańskie Miniatury - Kobiety nauki, http://gdanskieminiatury.ikm.gda.pl/ wp-content/uploads/2015/04/Kobiety_nauki_kolor.pdf , [dostęp: 16.08.2017]. 
we Lwowie. Pracę zawodową na Politechnice Lwowskiej rozpoczęła w 1919 roku jako asystent w Katedrze Geologii i Paleontologii. Z uczelnią związana była do 1946 roku. Przeszła przez wszystkie szczeble pomocniczego pracownika nauki, rozpoczynając jako młodszy asystent, a kończąc na stanowisku adiunkta. Pełniła ponadto funkcję kustosza Muzeum Mineralogiczno-Geologicznego. Po wojnie nie pracowała na żadnej uczelni, zawodowo związała się z przemysłem naftowym ${ }^{31}$.

Kolejnym wydziałem Politechniki Lwowskiej licznie reprezentowanym przez kobiety był Wydział Architektoniczny. Fakt ten nie znalazł jednak wyrazu w liczbie zajmowanych przez nie stanowisk naukowych na uczelni. W latach 1918-1939 stanowisko pracownika pomocniczego przypadło tylko jednej kobiecie i zaledwie na kilka lat.

Osobą tą była Irena Wieczorkowa, z domu Obmińska. Na stanowisku starszego asystenta Katedry Budownictwa Utylitarnego Politechniki Lwowskiej pracowała w latach 1925-1928. Była córką profesora Tadeusza Obmińskiego, architekta, rektora uczelni. Dzięki jej projektom powstało wiele domów ludowych, kolonijnych, starostw i kościołów we wschodniej Małopolsce ${ }^{32}$.

Droga kobiet w XIX wieku do pełnego dostępu do nauki była bardzo trudna. Pierwsze kroki kierowały na uniwersytety, o studiowaniu w szkołach technicznych tylko marząc. W konsekwencji, uczelnie techniczne nie brały czynnego udziału $\mathrm{w}$ dyskusji odnośnie ich edukacji i nie szukały rozwiązań prawnych umożliwiających kobietom studiowanie. Skutkiem tego na Politechnice Lwowskiej kobiety pojawiły się, w porównaniu z uniwersytetami, z dużym, bo 14-letnim opóźnieniem (zezwolono im studiować dopiero w 1911 roku). Odwołując się do dostępnych źródeł, sytuację kobiet na Politechnice Lwowskiej można odtwarzać dopiero od 1918 roku. Brak opracowań uniemożliwia wypełnienie luki pomiędzy rokiem 1911 i 1918. Wprawdzie udział kobiet w życiu Politechniki Lwowskiej od 1918 roku systematycznie rósł, jednak nie wpłynęło to znacząco na frekwencję i do 1939 roku pozostała ona na poziomie nieco ponad 4 procent wszystkich studentów. W dwudziestoleciu międzywojennym Politechnikę ukończyło około 180 kobiet, co stanowiło 3,8 procenta wszystkich absolwentów uczelni. Najwięcej dyplomów obroniono na wydziałach: Chemicznym, Architektonicznym i Rolniczo-Lasowym. Pozostałe wydziały ukończyło zaledwie kilka absolwentek. Ani jedna kobieta nie zdobyła tytułu inżyniera hydrotechnika i inżyniera leśnika ${ }^{33}$. Po

${ }^{31}$ M. Kamieński, Janina Syniewska (1893-1951), http://www.asgp.pl/sites/default/files/ volumes/22_4_522_523.pdf, [dostęp: 16.08.2017].

32 S.M. Brzozowski, Tadeusz Obmiński, http://www.ipsb.nina.gov.pl/index.php/a/tadeusz-obminski, [dostęp: 16.08.2017].

${ }^{33}$ J. Piłatowicz, Politechnika Lwowska w dwudziestoleciu międzywojennym. 
ujednoliceniu przepisów i wprowadzeniu w życie nowej ustawy oświatowej, w 1920 roku nastąpił przełom i bardzo szybko uczelnia zaczęła zapełniać się kobietami zatrudnionymi na etacie asystenta i adiunkta. Jeśli przeanalizować liczbę zajmowanych stanowisk względem czasu pracy, to wyniki są zaskakujące. Spośród 67 kobiet pracujących w latach 1918-1939 na stanowiskach asystenta i adiunkta, ponad połowa, czyli 35 osób, pracowała bardzo krótko, najwyżej rok lub dwa. Zauważyć można, że liczba studentek na wydziałach nie przekłada się na liczbę zajmowanych przez nie stanowisk młodszych pracowników nauki, ani na rozwój naukowy. Najwięcej asystentek pracowało na Wydziale Rolniczo-Lasowym, jednak krótko i niewiele z nich osiągnęło wysokie stopnie naukowe. Na architekturze również studiowało wiele kobiet, ale tylko jedna pracowała jako asystentka. Wydział Chemiczny wyróżniał się największą liczbą studentek, absolwentek i profesorek. Kobiety, które rozpoczęły pracę w latach 20., nie osiągnęły wyższych stanowisk w akademickiej hierarchii. Sytuacja zmieniła się diametralnie $w$ następnym dziesięcioleciu. Bardzo wiele kobiet zatrudnionych na Politechnice Lwowskiej kontynuowało swoją pracę naukową, osiągając dopiero po II wojnie światowej rangę samodzielnych pracowników naukowych.

W dziejach Politechniki Lwowskiej momentem przełomowym okazał się wybuch wojny. Odcisnął piętno na karierze naukowej i życiu prywatnym wielu związanych z nią kobiet.

Do takich osób należała Zofia Balówna. Zatrudniona na Politechnice Lwowskiej przez 10 lat, w Katedrze Fizyki jako asystentka, zakończyła pracę naukową w 1936 roku. Po wojnie podjęła obowiązki nauczycielki w szkole średniej34. Janina Szabatowska "Janka”, absolwentka Wydziału Chemii Politechniki Lwowskiej, pracowała na uczelni w latach 1926-1935 jako starszy asystent w Katedrze Chemii Rolnej i Gleboznawstwa. Od 1935 roku była kierownikiem Centralnego Laboratorium Kopalń Pszczyńskich. W czasie wojny udzielała się w Armii Krajowej i organizowała produkcję materiałów wybuchowych ${ }^{35}$.

Z Politechniką Lwowską związała swe losy także Ewa Neymanówna-Pilatowa. Jako „nieprzeciętna indywidualność naukowa”, będąc jeszcze studentką Politechniki Lwowskiej, rozpoczęła pracę na stanowisku asystenta. Duże zaangażowanie $\mathrm{w}$ pracy zaowocowało imponującym dorobkiem naukowym. Wspólpracowała z mężem nad rozbudową i organizacją Katedry Technologii Nafty i Gazów Ziemnych, dzięki czemu katedra ta stała się przodującym

${ }^{34}$ E. Iwaszkiewicz-Dobrzańska, Wspomnienia Elżbiety Iwaszkiewicz-Dobrzańskiej, http:/ / www.gce.gliwice.pl/jubileusz/wspomnienia2.html, [dostęp: 16.08.2017].

${ }_{35}$ W. Śmiśniewicz, Produkcja materiałów wybuchowych w wytwórniach Armii Krajowej w Warszawie w latach 1940-1944, Rocznik Warszawski, 2006, 34, s. 180. 
ośrodkiem w Europie ${ }^{36}$. W latach 1941-1944 pracowała w lwowskiej firmie „Laokoon”. Po wojnie rozpoczęła organizowanie Katedry Technologii Nafty i Paliw Płynnych na Politechnice Śląskiej w Gliwicach. Równocześnie pracowała na Politechnice Wrocławskiej. Wojna odcisnęła swe piętno na psychice tej uzdolnionej kobiety. Jedną z ofiar mordu lwowskich profesorów w 1941 roku był jej mąż, profesor Stanisław Pilat. Po wojnie, kiedy dotarła do niej wiadomość potwierdzająca ostatecznie listę nazwisk wymordowanych profesorów, zmarła w 1945 roku śmiercią samobójczą ${ }^{37}$.

Wojna i fakt, że uczelnia znalazła się poza granicami Polski, niewątpliwie wpłynęły na losy naukowe kobiet. Wiele z nich zrezygnowało z kariery naukowej, niektóre kontynuowały ją na innych uczelniach. Dumnie możemy wskazać te, które wniosły ogromny wkład w rozwój nauki polskiej. I były to osoby, które poprzez edukację czy pracę naukową zetknęły się z tą najstarszą uczelnią techniczną w Polsce.

\section{BIBLIOGRAFIA}

Beszterda M.M., Stryjeńska. Diabli nadali: Lambda alboskrzydła pod łózkiem: recenzje, http:/ / ksiazki.onet.pl/recenzje/stryjenska-diabli-nadali-angelika-kuzniak-recenzja/scf3ff [dostęp: 19.07.2017].

Brzozowski S.M., Tadeusz Obmiński, http://www.ipsb.nina.gov.pl/index.php/a/tadeusz-obminski, [dostęp: 16.08.2017].

Buda J., Materiały Seweryna i Heleny Krzemieniewskich (1871-1945; 1978-1966) (III-174), http:/ / www.petea.home.pl/apan/files/user_files2/biuletyn51.pdf, [dostęp: 16.08.2017].

Bunio P. i in., Idealistki, siłaczki, reformatorki: kobiety w nauce polskiej, Uniwersytet Łódzki, Łódź 2007.

Dominiczak A., Edukacja kobiet, http:/ / www.cpk.org.pl/plik,66,edukacja-kobiet-pdf.pdf, [dostęp: 19.07.2017].

Dorabialska A., Kisielow W., Stanistaw Pilat i Ewa Neyman-Pilatowa, http://archiwa. pilsudski.org / dokument.php?nonav $=0 \&$ nrar $=701 \&$ nrzesp $=74 \&$ sygn $=3 \&$ handle=701.180/2430, [dostęp: 16.08.2017].

Historia Muzeum Mineralogicznego Uniwersytetu Wroctawskiego i jego zbiorów, http:/ /www. muzmin.ing.uni.wroc.pl/teksty.php?plik=muzeum.php, [dostęp: 20.07.2017].

Iwaszkiewicz-Dobrzańska E., Wspomnienia Elżbiety Iwaszkiewicz-Dobrzańskiej, http:// www.gce.gliwice.pl/jubileusz/wspomnienia2.html, [dostęp: 16.08.2017].

Kamieński M., Janina Syniewska (1893-1951), http:/ / www.asgp.pl/sites/default/files/volumes/22_4_522_523.pdf, [dostęp: 16.08.2017].

Klimas K., In memory dr Maria Witkiewiczowa, http://gs.ing.pan.pl/35_PDF/GS35_69-70_ Witk.pdf, [dostęp: 20.07.2017].

${ }^{36}$ A. Dorabialska, W. Kisielow, Stanistaw Pilat i Ewa Neyman-Pilatowa, http://archiwa.pilsudski.org/ dokument.php?nonav=0\&nrar=701\&nrzesp=74\&sygn=3\&handle=701.180/2430, [dostęp: 16.08.2017].

${ }^{37}$ R. Mierzecki, Przemyst naftowy w Polsce w XIX i XX wieku, http:/ / docplayer.pl/6704159Przemysl-naftowy-w-polsce-w-xix-i-xx-wieku.html, [dostęp: 16.08.2017]. 
Kobieta i kultura: kobiety wśród twórców kultury intelektualnej i artystycznej w dobie rozbiorów i w niepodległym pańskie polskim, red. A. Żarnowska, A. Szwarc, Wydawnictwo DiG, Warszawa, 1996.

Kołodziejczyk A., Czy kobiety sa dyskryminowane w nauce? A w innych dziedzinach?, http:/ / pg.edu.pl/documents/1152961/1184550/calosc.pdf, [dostęp: 19.07.2017].

Kroh J., Wspomnienie o profesor Alicji Dorabialskiej, Zeszyty Historyczne Politechniki Łódzkiej, 2002, 1.

Kumaniecki W.K., Zbiór najważniejszych przepisów uniwersyteckich, [s.n.], Kraków 1913.

Mierzecki R., Przemyst naftowy w Polsce w XIX i XX wieku, http://docplayer.pl/6704159 -Przemysl-naftowy-w-polsce-w-xix-i-xx-wieku.html, [dostęp: 16.08.2017].

Młochowski J., Wspomnienie o profesor Zofii Skrowaczewskiej, Wiadomości Chemiczne, 1996, 50.

Murawski K., Gdańskie Miniatury - Kobiety nauki, http://gdanskieminiatury.ikm.gda.pl/ wp-content/uploads/2015/04/Kobiety_nauki_kolor.pdf , [dostęp: 16.08.2017].

Perkowska U., Kobiety w Uniwersytecie Jagiellońskim, https://forumakademickie.pl/fa-archiwum/archiwum/99/7-8/artykuly/kobiety_na_uj.htm , [dostęp: 20.07.2017].

Piłatowicz J., Politechnika Lwowska w dwudziestoleciu międzywojennym, http://bazhum. muzhp.pl/media//files/Kwartalnik_Historii_Nauki_i_Techniki/Kwartalnik_Historii_Nauki_i_Techniki-r1991-t36-n1/Kwartalnik_Historii_Nauki_i_Techniki-r1991-t36-n1-s25-70/Kwartalnik_Historii_Nauki_i_Techniki-r1991-t36-n1-s25-70. pdf, [dostęp: 20.07.2017].

Połowiński S., Prof. dr inż. Eligia Turska (1909-1996), Zeszyty Historyczne Politechniki Łódzkiej, 2007, 5.

Popławski Z., Wykaz pracowników naukowych Politechniki Lwowskiej w latach 1844-1945, Politechnika Krakowska, Kraków 1994.

Program Szkoty Politechnicznej we Lwowie na rok naukowy 1920/21, http:/ / delibra.bg.polsl. pl/dlibra/docmetadata?id=117, [dostęp: 20.07.2017].

Rozynek J., Doktorzy honoris causa Uniwersytetu Wroctawskiego 1948-1992, http:/ / uni.wroc. pl/o-nas/nagrody-i-wyr\% C3\% B3\% C5\%BCnienia/doktorzy-honoris-causa/bogus\%C5\%82awa-je\%C5\%BCowska-trzebiatowska [dostęp: 20.07.2017].

Smywińska A., W poszukiwaniu prababek - o pierwszych filozofkach z Uniwersytetu Jagiellońskiego (1897-1939) http://etyka.uw.edu.pl/wp-content/uploads/2013/6/45scrd/09Smywinska-w-poszukiwaniu-prababek.pdf, [dostęp: 20.07.2017].

Suchmiel J., Emancypacja naukowa kobiet w uniwersytetach w Krakowie i Lwowie do roku 1939, http:/ / dlibra.bg.ajd.czest.pl:8080/Content/2868/Pedagogika_13_115.pdf, [dostęp: 20.09.2017].

Szkolnictwo i oświata w Galicji 1772-1918, red. nauk. Julian Dybiec i in., Wydawnictwo Uniwersytetu Rzeszowskiego, Rzeszów 2015.

Śmiśniewicz W., Produkcja materiałów wybuchowych w wytwórniach Armii Krajowej w Warszawie w latach 1940-1944, Rocznik Warszawski, 2006, 34.

Terlecki R., Oświata dorostych i popularyzacja nauki w Galicji w okresie autonomii, Zakład Narodowy im. Ossolińskich, Wrocław 1990.

Walczak K., Prof. dr inż. Czestawa Troszkiewicz (1902-1985), http://www.chemia.polsl.pl/ stowarzyszenie/index.php/profesorowie/86-wydzial/profesorowie/122-prof-dr-inz-czeslawa-troszkiewicz, [dostęp: 20.07.2017].

Zajączkowski W., C. k. Szkoła politechniczna we Lwowie, nakł. Szkoły Politechnicznej, Lwów 1889.

Zamojska D., Akademicy i urzędnicy: kształtowanie ustroju państwowych szkót wyższych w Polsce 1915-1920, Instytut Historii Nauki Polskiej Akademii Nauk, Warszawa 2009. 